\title{
History textbooks, racism and the critique of Eurocentrism: beyond rectification or compensation
}

\author{
Marta Araújo and Silvia Rodríguez Maeso
}

(First submission July 2010; First published September 2011)

\begin{abstract}
This article is based on the theoretical framework developed within a research project on the construction of Eurocentrism and, more specifically, on the analysis of Portuguese history textbooks. We propose that the textbooks' master narrative constitutes a power-evasive discourse on history, which naturalizes core processes such as colonialism, slavery and racism. Showing the limits of an approach that merely proposes the compensation or rectification of (mis)representations, we argue for the need to unbind the debate on Eurocentrism from a perspective that fails to make problematic the 'very idea of Europe'. Accordingly, our analysis of Portuguese history textbooks focuses on three core narrative devices: (1) the chronopolitics of representation; (2) the paradigm of the (democratic) national state; and (3) the definitive bond between concepts and historical processes.
\end{abstract}

Keywords: Eurocentrism; race; racism; Portugal; education; history textbooks.

We need to tell a story about ways in which "Eurocentrism" as a category for the debate is hiding and obscuring something, obfuscating a debate, prepackaging a debate that thereby never really takes place and becomes, instead, this battle between bureaucrats over slots and curriculum.... the only way we get beyond a paralyzing either/or perspective is to take a look at this idea of Europe, the very idea of Europe as an ideological construct (West 1993, p. 120-1). 


\section{Introduction: textbooks and the politics of (mis)representation}

History textbooks, the main pedagogic resource used in classroom instruction in many contexts (Foster 2006), have been a battleground for disputes on national identity and a core concern in the teaching of history, particularly European history and identity (Council of Europe 1995, 1996; Pingel et al. 2000; Council of Europe 2001; Stradling 2001). Yet, within these debates, Eurocentrism has not been a key concern and its critique has been often skin-deep: the dominant understanding of Eurocentrism takes it as a perspective that can be challenged with the enlargement of national histories (e.g. teaching European and world history) and the validation of other cultural narratives (Soysal and Schissler 2005).

It is our view that this liberal tale of a 'kaleidoscope' of perspectives has been convincingly deemed insufficient and inefficient, as the mere inclusion of 'other' perspectives is not sufficient to overcome the hegemony of certain narratives. We thus argue for the need to open up the debate on knowledge and power, engaging with the frames of interpretation within which such perspectives are to be included. Thus, following West's argument, this article aims at showing the theoretical and analytical relevance of the notion of Eurocentrism for understanding the ways in which 'race' and racism are rendered (in)visible in the debate on nationhood, citizenship and democracy. We argue that the effectiveness of Eurocentrism lies not so much in prejudiced representations of the 'other', but in the de-politicization of power relations that make plausible such (mis)representations. According to Brown (2006, p. 15, emphasis in original):

Depoliticization involves removing a political phenomenon from comprehension of its historical emergence and from a recognition of the powers that produce and contour it. No matter its particular form and mechanics, depoliticization always eschews power and history in the representation of its subjects.

Our analysis shows that the textbooks' master narrative constitutes a power-evasive discourse. The main discursive formula of this avoidance of 'power and history' is the naturalization of core processes such as colonialism, slavery and racism, that is, the naturalization of the idea of Europe and of its central role in the development of the modern capitalist world system, scientific thought and liberal democracy, read as achievements within a progress rationale (Wallerstein, 1997). Focusing on this evasiveness is crucial to understand how Eurocentrism is constructed and reproduced and to challenge the idea that a more critical pedagogy and history (as well as other disciplines) can be achieved by merely including other perspectives and versions. 
Only thus can we overcome the process of critique as a matter of 'false' and 'erroneous' representations, and engage with the power relations that pervade the production of knowledge and interpretations.

We conceive of Eurocentrism as a paradigm rooted in what Quijano (2000, pp. 533-9) designated as the (global) 'colonial/modern capitalism' inaugurated with the colonization of 'America' in the fifteenth and sixteenth centuries, marked by two interrelated processes: the construction of the idea of 'race' and the establishment of a diversified structure of control of labour. Eurocentrism, now hegemonic, is a paradigm that organizes the production of interpretations of social reality (past and present), while masking its ideological basis under the pretence of political and scientific neutrality. More precisely, whereas Eurocentrism is tied to the modern configuration of 'race' and racism, it produces a frame of interpretation that masks this history, as illustrated by our analysis.

This article draws on the theoretical framework developed within a research project ${ }^{1}$ on the construction of Eurocentrism and, more specifically, on our analysis of Portuguese history textbooks, taking into account the specific contexts of their production and consumption. $^{2}$ The project is centred on three processes: (1) analysis of textbooks and education policy; (2) interviews and focus groups with a variety of actors; and (3) participatory workshops. The project takes a broad approach to these debates. Avoiding locating schools within a sociopolitical vacuum, the empirical work of the project engages with a diversity of actors operating in this field of symbolic power relations. In order to unravel such relations we worked on: (1) the production and dissemination of historical knowledge; (2) the linkages between public policies, the curriculum and textbooks; (3) the writing and producing of textbooks; (4) the pragmatics of school teaching; and (5) the participation of media and civil society organizations on related debates. Throughout the research, discussions with these actors were promoted through the use of qualitative methodological strategies aiming to expand the social impact of the project.

History textbooks were analysed in a systematic fashion, through the development of a grid of concepts. A critical approach to content analysis was used, also taking into account that which was made absent (Apple 2004a). We analysed the five most popular textbooks in the school year 2008-9, ${ }^{3}$ at Key Stage 3 (Years 7, 8 and 9, for pupils aged twelve to fifteen). ${ }^{4}$ Throughout compulsory education, history is taught in three different moments, in an increasingly sophisticated fashion, that is, in a 'spiral curriculum' (Cruz 2002, p. 328). Key Stage 3 was chosen as the syllabus for these school years includes world, European and Portuguese history, from 'prehistory' to contemporary 
times. Within the syllabus, we analysed in detail the themes/historical periods listed in Table 1.

The text is divided into three sections. First, we examine key debates on education, history and Eurocentrism, arguing that current academic approaches have a limited potential. We then explore in detail the analytical lines developed from our reading of textbooks, taking into account the specificities of the Portuguese context. Finally, we conclude this article by considering the limits of compensation and rectification within the frame of Eurocentrism as a paradigm. The textbooks cited in this article are listed in the Appendix.

\section{Eurocentrism in textbooks: debates on power and history}

In education, debates on Eurocentrism have often focused on representations without engaging adequately with the relation between knowledge and power. In particular, curricula and textbooks have been frequently used to study representations of the 'other', in binary opposition to a 'we' that tends to remain implicit and unquestioned (Hall 1992). Framed as a matter of the absence of representation and the mis-representation of the 'other', such research has important theoretical shortcomings: it approaches Eurocentrism as an equivalent to ethnocentrism (a mere situated perspective) and it frames racism as 'error' or 'ignorance' (Lesko and Bloom 1998). Focusing more on the incorrectness of certain representations than analysing the frames of interpretation within which they are located, research has failed to produce critical approaches to core processes such as colonialism, slavery and racism. This is related, in our view, to a positivist approach to history that frames it as a question of producing 'balanced' narratives between 'the good' and 'the bad' sides:

An individual's identity is not predestined; it is always in a state of becoming; evolving in response to life's experiences. The same applies to national identity. It has been shaped by and continues to be shaped by shared experiences - both positive and negative,

Table 1. Key themes/historical periods under analysis

Year 7 From the hunter gatherer societies to the first civilizations The formation of western Christianity and Islamic expansion

Year 8 Expansion and change in the fifteenth and sixteenth centuries Portugal in the European context of the seventeenth and eighteenth centuries

Year 9 Europe and the world at the turn of the twentieth century From post-World War II to the 1980 s Cultural challenges of our times 
glorious and dark, admirable and shameful. Multiperspectivity in the teaching of national history focuses on how people have come to be what they are today. (Stradling 2001, p. 151)

Previous research, particularly in the USA following the struggles by the Civil Rights Movements of the mid-1960s (Apple 2004b; Foster 2006), has shown the limits of a positivist approach based on the addition of multiple voices and perspectives (e.g. Swartz 1992). Such a compensatory approach, it is argued, fails to deal with the power arrangements that shape the inclusion and representation of the 'other' in school curricula in ways that do not challenge the 'master script' (Swartz 1992, pp. 342-4). ${ }^{5}$

This also became clear in our preliminary analysis of Portuguese history textbooks, particularly the section dealing with the national liberation wars that started in Angola in 1961. The perspective of António Salazar (a key figure of the authoritarian Estado Novo that ruled Portugal from 1926 to 1974) is contrasted to that of Amílcal Cabral (the founder of the African Party for the Independence of Guinea and Cape Verde and a leader in the struggles for national liberation), in ways that fail to challenge the master narrative:

Doc. 4 Salazar, Discourses, Coimbra, 1957 (adapted)

... the route followed is defined by a strategy of integration into a Unitarian State, composed of dispersed provinces and of different races...We believe that there are decadent races or races lagging behind - as one wishes -, in relation to whom we share the duty of calling them to civilisation.

Doc. 5 Amílcar Cabral, Selected Works, Lisbon, 1972 (adapted)

To Africans, Portuguese colonialism is hell.... Portugal is an underdeveloped country, with $40 \%$ of illiterate people, and the lowest standards of living in Europe. If it could achieve a civilising influence on any people it would be kind of a miracle.... (NH9, p. 179)

In the same page, the textbook features a picture entitled 'Portuguese soldiers captured by Angolan guerrilla men', in which a group of uniformed soldiers and possibly locals (totalling fifteen people) circles two dead Portuguese soldiers, lying on the floor. The war is not contextualized politically, and therefore Cabral's discourse emerges as a critique of the incompetency of Portuguese colonialism, rather than of colonialism itself. As a result, the legitimacy of colonialism is never questioned. This illustrates the limits of a multi-perspective approach to challenge the wider power arrangements in which different perspectives are to be accommodated. While addressing relevant 
issues, this construction of the debate - as a matter of promoting multi-perspectivity and enlarging the school history canon beyond the West - has not challenged Eurocentrism as a paradigm.

Arguing that, in much work, Eurocentrism becomes an adjective or a foregone conclusion, we propose to take the debate further and to challenge the idea of the 'multicentred curricula' as a panacea. In our view, the challenge to overcome the deep-seated Eurocentric knowledge productions in western academies is considerable. As Grosfoguel $(2009$, p. 14) reminds us, we should remain critical of 'an epistemic populism where knowledge produced from below is automatically an epistemic subaltern. ${ }^{6}$ We therefore reinforce the idea that in 'every historical period, competing paradigms and forms of knowledge coexist' and that 'the groups who exercise the most power within a society heavily influence what knowledge becomes legitimized and widely disseminated' (Banks 2004, p. 29). Thus, while by no means implying that other perspectives and historiographies are not necessary, we argue that any alternative to hegemonic narratives needs to be framed within its struggle for political legitimacy, scientific validity and educational relevance.

The development of multi-perspectivity has also been linked, mainly in European contexts (Council of Europe 1995; Council of Europe 1996; Stradling 2001), to the concern with the transformation of national narratives ${ }^{7}$ the misuses of history for nationalistic purposes, and particularly with the abuses of nationalistic history - paramount to dictatorial regimes (eventually overcome by processes of democratization). In Portugal, illustrative of such debate is the general focus of research on textbooks on the dictatorial period of Estado Novo, which results in taking dictatorships as the time of the misuses of history and in constructing as burlesque the excess of nationalism (e.g. Almeida 1991; Carvalho 1997; Santos 2007). For instance, Santos (2007, p. 358) focuses on this period to demonstrate that textbooks promoted by the dictatorship 'influenced (children's) world visions' and promoted 'a nationalistic and imperialistic spirit' (Santos 2007, p. 358). Such approach, albeit unintentionally, paves the way to the idea that the scientific production of history was unproblematic (i.e. neutral, not biased) both before Estado Novo and following democratization in the mid-1970s.

We thus defend a broader understanding of Eurocentrism that allows for the contextualization of textbooks as part of an epistemology of history. As Lesko and Bloom (1998) have argued regarding multicultural education, what is at stake is not so much the confrontation between different versions of history, but rather the production of interpretations that can unsettle positivist approaches to the neutrality of scientific knowledge and the presumption of irrationality/ignorance lying behind certain 'judgments', such as 
racism. This perspective can give us an analytical path beyond the 'too-easy West-and-the-rest polarization' (Spivak 2003, p. 39) that merely reproduces a centre/periphery historical narrative.

\section{Portuguese history textbooks: a 'race'/power evasive discourse}

We consider Portuguese textbooks as an example of the contemporary configuration of Eurocentrism, and therefore in this article we engage with the specificities of debates on colonialism, 'race'/racism and nationhood in that context.

In Portugal, the politics of history teaching and textbooks is rooted in the republican educational project. Since the second half of the nineteenth century, and strongly influenced by positivist pedagogy, it constructed a 'nationalist and colonialist discourse' with the hope of 'regenerating' the country (Proença 2001, pp. 50-1). Hence political discourses and particularly republican campaigns over colonial questions, marked by the impact of the 1890 British Ultimatum, invested in the imaginary of 'Portugal's golden age ... equated with the Expansion and the spirit of the "Discoveries"; an epoch of national affirmation but also of scientific pioneering and "modernity"" (Vakil 1996, pp. 44-5). Moreover, colonial discourses and legislation enacted the thesis of Portuguese exceptionality. This could supposedly be seen in its universalist and humanist colonialism and in the racial tolerance of its national character. This was an argument reinvented by the dictatorial regime in the 1950s (Castelo 1998; Alexandre 1999) ${ }^{8}$ and since the late 1980 s by sectors of the political administration and the academia (Vakil 1996).

These specificities define the particular contours of Eurocentrism in Portuguese textbooks, while embedded in a globalized hegemonic paradigm of historical interpretation. In order to systematize our analysis, we distinguished three main lines that relate to: (1) the use of time/space for the construction of a logical historical narrative; (2) the establishment of the national state and the process of democratization as the commonsensical representation of society and politics; and (3) the tying of concepts and historical processes, presented as logically bounded, and particularly evident in the notions of 'race' and racism.

The chronopolitics of representation: history as a 'moral success story'

The anthropologist Johannes Fabian (2002, p. 25, emphasis in the original) used the term 'coevalness' ${ }^{\prime}$ to critically analyse 'how anthropologists use Time in constructing their theories and composing their writings'. Fabian considers that anthropology, as a discipline and as a discourse, has denied coevalness through the "persistent and systematic tendency to place the referent(s) of anthropology in a Time 
other than the present of the producer of anthropological discourse' (Fabian 2002, p. 31). In a similar fashion, history textbooks, subsuming the 'other' into a linear narrative, locate the latter in a radically different time from the 'European', that is, the 'other' remains at an inferior stage of civilization and humankind's development. This naturalization of time is geographically legitimated: the first human species appeared in 'Africa', but the processes of sedentarization and of complex social differentiation took place in Egypt (depicted as outside Africa), the Middle East and Europe (VH7-1). The section in this textbook entitled 'From the hunter gatherer societies to the first civilisations' is illustrative. The picture of a man (a peasant) holding a hammer is described as 'Herding in a present-day village (Niger, Western Africa)', with the following clarification:

Similarly to what happened during the Neolithic Age, rudimentary agriculture and herding is practised in this village. One of the agricultural utensils still used today is the polished stone hammer.... Establish a comparison between the way of life of this population and that of the Neolithic Age. (VH7-1, p. 22). ${ }^{10}$

This understanding of other peoples as located in a remote age (i.e. the Neolithic, the Stone Age) mobilizes a temporal device paradigmatic of the modern representation of difference as distance (Fabian 2002, p. 16): 'There are still in our present times hunter peoples from the Stone Age that live in the Amazonia and in some Pacific islands' (LH7, p. 17). Regarding Egyptian civilization, however, the text (VH71, p. 35) states: 'The agricultural techniques of Ancient Egypt are still used in present times, such as the plug, the construction of dikes and drainage techniques to distribute water all over the land.' The linear timing locates the 'African village' in a different time (the Neolithic) and at a different stage of development (rudimentary), whereas 'Egyptian civilization' - overlooking that it is in the African continent is still present in our scientifically advanced societies, as we can appreciate from the enduring use of their techniques. This thus establishes which society 'qualifies' for the status of civilization and the location of the people who still live in archaic conditions. Following Wolf (1997), this representation of time and space 'turns history into a moral success story' - that of modernization which, since the nineteenth century, has become 'an instrument for bestowing praise on societies deemed to be modern and casting a critical eye on those that had yet to attain that achievement' (Wolf 1997, p. 12).

An important consequence of this Eurocentric and authoritarian representation of time and space is the fixing of certain (racial, ethnic) markers and postures as belonging to specific territories. Accordingly, 
decontextualized images of black people in a suffering/violent posture are deployed to represent contemporary Africa:

Regarding Document 4 (picture of starving black children with empty plates in their hands, waiting for food):

- Identify the level of development of the people represented;

- Identify the continent where nowadays there is a larger number of countries with the same level of development;

- Relate this level of development to the process of decolonisation;

- Give two examples of NGOs that try to respond to the problems of these populations. (NH9, p. 169)

Students are thus expected to internalize a pattern of recognition/ representation, expressed in the following equation:

[black] Africa $=$ failed decolonization $=$ underdevelopment $=$ requ ired [western] humanitarian intervention

A paradigm of social, economic and political organization: the (democratic) national state

'The notions of society and Europe, what do they suggest to you?' (VH7-2, p. 22).

The complex process of the nationalization as the homogenization of society (Tilly 1992, 1994), that is, the constitution of 'the social' as 'the nation" (one community, one language, one culture, in a wellbounded territory) is naturalized and reified in textbooks. This is a crucial feature of those implicit constructions of 'selfhood' that underwrite the representation of the 'other' because their core narrative authorizes a paradigm of political organization - the democratic national state. This perspective does not only render invisible other forms of the political as, more importantly, it neglects the political features of different forms of organization. Accordingly, Africa - with the exception of Egypt - is presented as an empty land with no complex social and political organization until the Europeans arrived there (Wolf's 'ethnographic present', 1997, p. 95) and where, instead of nations, 'we' found tribes or indigenous chiefs, ${ }^{12}$ thus, the notion of 'Africa' only becomes meaningful when related to what Europeans and the Portuguese, possessed, achieved and designated in that territory:

The objective of the Portuguese in Africa was trade [fifteenth and sixteenth centuries]. From Morocco to Senegal, they traded with tribes of nomad Moors that lived in the Western Saharan region. Further south, they traded with the "Guinéus" ["Guineans"], the 
designation given by the Portuguese to the inhabitants of Black Africa. (H8, p. 38)

Portuguese history textbooks reify not only the idea of the nation state but also of Europe. Such historical formations are subsumed under a teleological discourse that makes sense according to the 'final result', i.e. the European Community. ${ }^{13}$ For instance, the period between the sixth and the ninth centuries - the barbarian invasions - emerges as a time when, paradoxically, Europe invades Europe:

Europe under threat. Fear and insecurity. Western Europe was characterised by a climate of great insecurity since the fifth century, due to the barbarian invasions. This atmosphere was aggravated with the new wave of invasions that Europe suffered between the $7^{\text {th }}$ and $10^{\text {th }}$ Centuries. Three were the attacking peoples: the Muslims, the Normans and the Hungarians. Europe felt threatened and entrenched for more than two centuries. (LH7, p. 128)

The national state paradigm is presented as the process of both Christianization and of democratization. Significant parts of two textbooks are dedicated to 'The formation of Western Christianity and Islamic Expansion', from the sixth to the thirteenth centuries (VH7-2; LH7), with subtitles such as 'The birth of Western Christian Europe', 'The Catholic Church in Western Europe' and 'Europe under threat'. Therefore, the following historical formation and collective identity is established:

[white] Portugal $=$ the national state $=$ Western Christian Europe [the Roman Catholic Church]

There is a naturalization of the relation between society and a culturally homogeneous nation deployed in contrast to the heterogeneous, nomad (stateless) 'tribes"14 found by the Europeans in the African context; this equation is clear in the interpretation of the processes of independence of the North American colonies: 'The Independence of the United States of America: all these colonies had common bonds: the majority of the population spoke English and practiced the Protestant religion' (LH8-2, p. 16). As the map in Figure 1 shows, the expansion of the national state paradigm thus sees its turning point with the 'Liberal revolutions', epitomized by the American and French Revolutions. These processes show the intellectual interrelation between the Americas and Europe, which combined Christianity and nationalism. Political processes in other regions (such as Africa and Asia) are not considered relevant, as they do not match those 


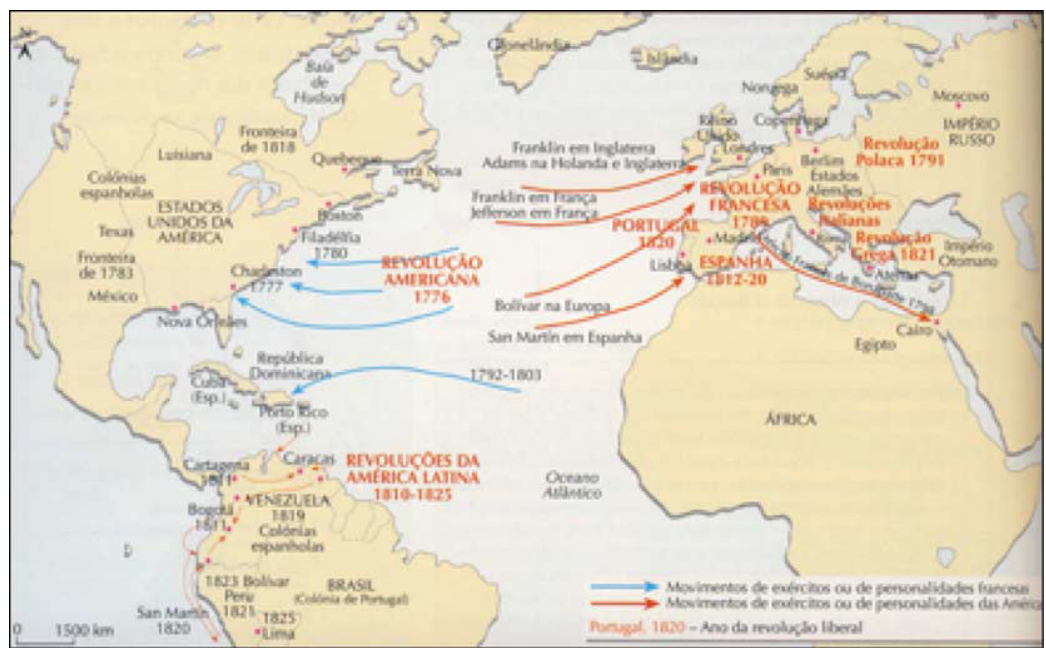

Source: SH8, p. 114

'revolutionary' processes that engendered the ideals of modern citizenship and liberal democracy.

Whereas the American Revolution is depicted as a successful process of nation formation and democratization, the processes of 'independence' in twentieth-century Africa and more precisely, the socalled Colonial War between Portugal and the African colonies, are considered not so much as a political process, but rather as 'guerrilla warfare'; the images deployed highlight the violent character of the guerrilla: 'Portuguese soldiers captured by Angolan guerrilla troops' (NH9, p. 179). In a similar fashion, the narrative describes the Portuguese colonizers' violent behaviour as defensive, whereas the Angolan guerrilla is depicted as murderous:

A generalised feeling of fear among colonial settlers led them to kill many indigenous people, while some of the latter ran away to join the guerrilla movement. Afterwards, tribes from Northern Angola murdered hundreds of colonial settlers. (NH9, p. 178)

The description of the Angolan guerrilla troops as 'tribes' is important because contemporary 'Africa' is usually described as a failed continent (the failure of national states), trapped in corruption, poverty and internal violence; for instance, a picture showing a group of armed black men has the following footnote: 'Internal conflicts in an African country, present days' (NH9, p. 162). As argued above, the 
violent and the suffering (black) Africa are two sides of the same coin, authorizing not only certain decontextualized representations of power relations but also the requirement for western (humanitarian) intervention:

Until recently, the history of Portuguese capitalist colonial genocidal practices was written from a white man's perspective. The West persists in positioning Africa as a continent without human political solutions, and the mainstream media depicts Africa as a "red cross" problem. That is, there is no political solution for the African continent. (Paraskeva 2006, p. 250)

\section{Racism within the definitive bond between concepts and historical processes}

Socio-historical studies have demonstrated that it was in the second half of the eighteenth century, within the Enlightenment's growing centrality of scientific and empiricist rationality, that the idea of 'race' entered common usage. At the time, it was used to refer to discrete categories, empirically observable, according to phenotypical traits (Mosse 1998; Hannaford 1996; Solomos and Back 1996). Nevertheless, we argue that it is crucial to consider that racially defined discourses and administrations of populations have existed without a clear concept of 'race' - scientifically sustained - that refer to bounded groupings of human beings. The governing of populations based on racial ideas was already in place in the fifteenth-century Iberian peninsula, illustrated by the idea of 'purity of blood' in the persecution of New Christians (Fredrickson 2002) or in the construction of the category 'Negro' as an equivalent to slave (Sweet 2003). This is of great importance for the analysis of Portuguese textbooks regarding two aspects: on the one hand, the conceptual shrinkage in the understanding of racism (reduced to an extremist ideology) and, on the other, the establishment of a definitive bond between racism, nineteenth-century imperialism and the Nazi regime.

All textbooks analysed refer to racism for the first time in the period at the turn of the twentieth century, focusing on imperlialism and colonialism and emphasizing the British and French cases. Subsequently, racism is thoroughly discussed as a prejudice characteristic of the Italian and German totalitarian regimes of the 1930s and 1940s (LH9-1; NH9). Racism is only mentioned again in relation to the 'situation of minorities' in western societies during the 1950s and 1960s, using the $\mathrm{Ku}$ Klux Klan as an example of a 'racist organisation' (LH9-2, p. 46). We thus consider that textbooks reinforce a Eurocentric concept of racism that associates it with 'some form of 
extremism or exceptionalism, rather than something more conventional and mainstream' (Hesse 2004, p. 14; see also Gilroy 1992). This linkage of racism and racial discourses to very specific projects, such as the nineteenth-century imperlialist enterprise, locates racism in the colonial territories while conceiving these as outside and unrelated to Europe. Such an approach hinders a broader understanding of "the interaction between racism as a modern political project and the European nation-state' (Lentin 2004, p. 36), beyond the Nazi state and anti-Semitism. Following Hesse (2004, p. 14), this can be seen as the double bind that operates in the (Eurocentric) concept of racism: 'the concept of racism is doubly-bound into revealing (nationalism) and concealing (liberalism), foregrounding (sub-humanism) and foreclosing (non-Europeanism), affirming (extremist ideology) and denying (routine governmentality).'

Furthermore, it is fundamental to emphasize the historical shrinkage that confines racial governmentality to the so-called 'new Imperialism' (LH9-1, p. 14) and the Western European countries 'greed for Africa': 'Europeans considered it was their duty to bring their "superior civilisation" to the less-developed peoples. Africa was thus the most desired continent' (LH9-1, p. 16). The textbooks analysed do not consider racial differentiation and racist governmentality within the Portuguese and Spanish 'expansion' and the systems of slave trade and slavery. Slave trade is mainly depicted as part of the 'circulation of new products' between Europe and the other continents (LH8-1: 38, 46; NH8-1: 38; SH8: 46). Following Swartz's study of American history textbooks, we also consider that in the Portuguese textbooks analysed, 'slavery discourse... generally serves to justify and normalise the system of slavery' (Swartz 1992, p. 345). Slavery thus appears 'more as a necessity, not as a choice, implying that slavery was natural, inevitable, and unalterable' (Swartz 1992, p. 345):

Portuguese presence in Black Africa. The climate in São Tomé is hot and damp and the soil is quite fertile. The Europeans, however, were deeply affected by tropical diseases, particularly malaria, and it was mainly thanks to the African slave labour that a dynamic sugar production was settled. The two archipelagos [São Tomé and Cape Verde] became entrepôts of the slave trade. Slaves were acquired in the African coast and thereafter re-exported to Europe and the American continent. (LH8-1, p. 38, emphasis in the original)

The de-politicized accounts of Portuguese colonialism guarantee the absence of a discussion of racism and racial consciousness before the 
emergence of specific racist ideologies and theories of 'race' in the late eighteenth century; this is key to understanding the prevalence of a discourse that underwrites the 'good sides of colonialism' in terms of multiculturalism and cultural contact. On the contrary, we consider that the historical period characterized in textbooks as the 'Expansion' or the 'Discoveries' was crucial for the emergence of hierarchical racial classifications and of racist governmentality: ${ }^{15}$

The sixteenth century thus marks the divide in the rise of race consciousness. Not only does the concept of race become explicitly and consciously applied but also one begins to see racial characterization emerging in art as much as in politico-philosophical debates.... while slavery may be explained largely (though not nearly exhaustively) in economic terms, one must insist in asking why it was at this time that racial difference came to define fitness for enslavement and why some kinds of racial difference rather than others. (Goldberg 2002, p. 287)

Some textbooks focus rather on the 'degrading conditions' under which those enslaved were treated, stressing a moral narrative on the 'inhumanity' of slavery (LH8-1, p. 39). Thus, rather than an articulated discourse on racism, ${ }^{16}$ euphemisms pervade a benevolent and compassionate discourse on 'circulation', 'acculturation' and 'miscegenation', which is illustrated by the following passage:

The practice of slavery, the large-scale transportation of African population to America and Europe, gave rise to miscegenation (the mixing of races) and sometimes created among Europeans a feeling of superiority in relation to the indigenous peoples. This attitude, however, brought about in some European minds, namely members of the clergy, an awareness of the need to defend these peoples antagonised by others. Moreover, maritime expansion led to a broader understanding of Nature. (LH8-1, p. 39)

Racism is (not) named with the euphemistic 'sentiment of superiority', and therefore not considered as a 'routine governmentality' (Hesse 2004, p. 14) structuring society and politics, but as an 'attitude'. Conceived as an individual disposition, racism can be combated in the same way some 'members of the clergy' did in those times. This is an example of the deployment of a moralizing approach to speak of racism, prevalent in the textbooks analysed: challenges to violent and unjust socioeconomic and cultural structures are regarded as a topdown process, attributed to the 'good people' in power, whose immersion within the colonial ideology is masked. The narrative shifts the focus onto the humanitarianism of the clergy. Within this humanist 
take on difference, empathy ${ }^{1 /}$ emerges as the only available device to approach the 'other'. ${ }^{18}$ In the textbooks analysed, empathy is deployed to favour the identification of the reader with the feelings of the victim i.e. the 'slaves' - facilitating the cognitive and emotional understanding of the victim's suffering: ${ }^{19}$

Write a text to be titled Living and Working in a 17th-century Brazilian Sugar Mill...

Which sufferings did slaves experience, during transport and captivity? Were they truly considered and treated as human beings? Which moral opinions did - and still does - this drama elicit? (LH81, pp. 97-8)

Empathy with the enslaved emerges as a way of sustaining a humanist and moralizing view that evades issues of power/'race' and is incapable of questioning the master narrative that runs throughout the textbooks, consistent with a view of slavery and colonialism as an evil located in the past. The shortcomings of this narrative formula based on empathy are also evident in a section on the Nazi regime, where racism is addressed regarding the participation of Jesse Owens, the black American athlete, in the 1936 Summer Olympics in Berlin and Adolf Hitler's attitude to his achievements. Next to the picture of him collecting a medal, it is asked 'What would Jesse Owens feel when he went to collect his fourth medal at the podium? Why?' (LH9-1, p. 159). While the students are invited to walk in his shoes, racism is framed as something morally 'wrong', happening to individual, powerless victims. Victims are thus presented as lacking any meaningful political action in those historical processes (seen in the way the history of abolitionism or colonial independencies are told).

In the textbooks analysed, the underlying assumption seems to be that teaching students knowledge about the feelings of victims will result in their sympathy and change of attitudes towards oppression. Yet, empathy alone cannot contest the broader de-politicized narrative being deployed. Indeed, as Johnson (2005, p. 44) suggests, empathy may be 'managed, limited, and restrained' in ways that do not challenge subordination. We thus argue that the framing of the debate within a moral, binary opposition - the good victim vs the bad aggressor - is not capable of questioning the structural role played by colonialism, slavery and racism in western societies.

\section{Conclusions}

This question of the "encounter of cultures"... became central in the new commemorative cycle opened in $1986 \ldots$... For what it 
suggests and mostly for what it attempts to hide, this new formulation of the "encounter" is a much more demagogical rhetoric move than the former one ["discovery"]... Nevertheless, the collective spirit promoted by the idea of the "encounter of cultures" was positive.... this image has functioned as a factor promoting humanistic and anti-racist values. In any case, a clarification of the memory of the expansion can only result in the fostering of a more complex and plural approach to history, the same strategy that was explicitly adopted in 1996. For technical reasons of rigueur, for the adequacy to an ecumenical pedagogy and, finally, for the ethical sense linked to the duty of amending cultural biases within the approach to the other. (Hespanha 1999, pp. 18-9)

In Portugal, when discussing the teaching of history, it is important to consider the work of the National Commission for the Commemoration of the Portuguese Discoveries (1986-2002), established to coordinate the activities marking the fifth centenary of the 'Discoveries', which invested in research on historical sources and in the production of pedagogical resources. The Commission played a crucial role in projecting a renovated portrait of Portuguese national identity and of its colonial history: the reading of the 'Discoveries' as an 'intercultural dialogue' and of the Portuguese as 'cultural mediators', thus replacing the New State's version of 'racial mediators' (Vakil 1996, p. 36). Accordingly, we see Hespanha's ${ }^{20}$ assessment of the Commission's work as embedded in a dominant perspective on the benefits of a 'more plural history', which is also present in debates on textbooks and school history. As argued throughout this article, we see multiperspectivity as limiting the possibility of adequately challenging Eurocentrism and Eurocentric notions of racism. That is, the positivist approach that proposes 'complexity' and 'clarification' - a more rigorous knowledge of the history of the 'Expansion', in this case merely paves the way to the balance between the positive and negative sides of history and the rectification of wrong, biased representations of the other.

Understanding Eurocentrism as a paradigm requires consideration of the enactment of specific power relations and the devices through which narratives work (e.g. the interplay of notions like time, place and national state). A clear example is the deployment of time/space that conveys explanations of difference as being either 'deficient' (underdeveloped, violent) or 'alike' (part of civilization, achieving independence as national states). This pattern secures a reading of history and particularly of modernity as a tale of 'Europe's' achievements, and thus of world capitalism and liberal democracy as the inevitable accomplishment of 'being modern'. 
What is at stake is the relation between power and knowledge within the configuration of core patterns of interpretation/representation/ recognition. Albeit in a more sanitized manner, the failure to overcome rectification or compensation is legitimizing colonialism and naturalizing racism.

\section{Notes}

1. The project 'Race' and Africa in Portugal: A Study on History Textbooks (2008-2011) is funded by the Foundation for Science and Technology (ref. FCOMP-01-0124-FEDER007554, within the EU programme COMPETE).

2. We are aware that textbooks have a multiplicity of readings and are used in different ways within the pragmatics of history teaching. Yet our focus in this paper is not on everyday teaching practices but on how textbooks embody specific politics of representation.

3. Selection of the textbooks in most common usage in schools was based on information provided by the Ministry of Education.

4. Key Stage 3 is the only stage in compulsory schooling in which history is taught separately as a subject, even though officially there has been a call for its merger with geography. Currently, history teaching has a ninety-minute time slot.

5. The correction of misrepresentations through the use of multi-perspectivity has been often uncritically endorsed in the field of inter/multicultural education. For instance, Borg and Mayo (2006, p. 151) treat Eurocentrism as a matter of 'misconceptions', 'lack of basic knowledge' and 'distortions', despite recognizing the limits of such an approach and alluding to the operation of 'Western regimes of truth' (Borg and Mayo 2006, p. 153). Therefore, the challenge is perceived as a matter of re-centring the 'subaltern' to achieve multicentred curricula (Borg and Mayo 2006, p. 158).

6. For a detailed discussion on the difficulties in formulating alternative epistemologies, see Grosfoguel (2009).

7. Regarding this, the processes of transformation in textbooks and curricula are usually framed as an issue of the representation of the 'other' (i.e. minorities and immigrants) and its effect on the (national) dominant narrative, in an 'either/or' perspective (e.g. Soysal and Shissler 2005, p. 7), rendering Eurocentrism as the aforementioned condition of adjective or foregone conclusion.

8. Salazar's regime partially drew on Gilberto Freyre's work, enunciated as Lusotropicalism in 1952 (Castelo 1998).

9. From the Latin coaevus, referring to people and things that exist at the same time, that coexist.

10. All translations are our own.

11. It is important to note that the history of western social sciences, and more specifically of sociology and political science, is tied to the configuration of the modern national states; therefore, the conceptualization of 'the social' has been equated to that of the national state (Wolf, 1997). For a discussion of the crisis of this mode of categorization in the field of sociological theory and analysis, see Pérez-Agote (1996).

12. We have found only one map that represents processes of political organization in Africa, registered with terms such as 'African states', 'Kingdoms' or 'Empires' (H8, p. 38). 13. The numerous symposia and conferences organized by the Council of Europe on the teaching of history and history textbooks since the 1950s have stressed the importance of promoting the 'European dimension of education through history' (Council of Europe 1995, pp. 10-11).

14. As Lentin (2008) underlines, in the footsteps of Goldberg's analysis of Hobbes' theory of the state (Goldberg 2002: 39-45), '[the modern state] stood in contrast to the chaos represented by statelessness. In the context of the "discoveries", the territories inhabited by 
racial others were representative of statelessness. The fathers of European philosophy all referred to the lives of "natives", "savages", "Indians" or "Negroes" to exemplify their conceptions of the State of Nature' (Lentin 2008, p. 25).

15. In this sense, we consider that some literature seems excessively concerned with the emergence of the idea of race (as fixed biological differences between human groups) and, therefore, they confine the 'modernity of racism' to the eighteenth-century Enlightenment (e.g. Lentin 2004), disregarding the particularities of racial governmentality before that period.

16. See also van Dijk (1993).

17. We make a distinction between empathy - imagining another's emotions or perspectives ('walking in one's shoes') - and sympathy - a shared emotion, including a feeling of pity or contempt that does not require empathic understanding. Some authors (e.g. Schaap 2001) use the concept of sympathetic identification as an equivalent to empathy.

18. The Sofia Symposium on 'History, democratic values and tolerance in Europe' organized by the Council of Europe, recommended that 'attitudes such as empathy and acceptance of diversity' should be encouraged within history curricula (Council of Europe 1995, p. 64).

19. Boltanski (2007, p. 90) stressed how this 'reflexive device' on humanitarian discourses envisages constructing the 'moral spectator' (le spectateur moral) through the inclusion of his/her feelings within the description of the other's suffering. See also Sontag (2004).

20. Hespanha was the Committee's chief commissioner from November 1995 to February 1999.

\section{References}

ALEXANDRE, VALENTIM 1999 'O Império e a Ideia de Raça', in Jorge Vala (ed.), Novos Racismos, Oeiras: Celta, pp. 133-44

ALMEIDA, MIGUEL VALE 1991 'Leitura de um livro de leitura: a sociedade contada às crianças e lembrada ao povo', in Brian O'Neill and Joaquim Pais de Brito (eds), Lugares d'aqui, Proceedings of the Seminar 'Terrenos Portugueses', Lisboa: Publicações D. Quixote APPLE, MICHAEL 2004a 'Cultural politics and the text', in Stephen J. Ball (ed.), Sociology of Education, London: Routledge Falmer, pp. 179-95

2004b Ideology and Curriculum, 3rd edn, New York: Routledge Falmer

BANKS, JAMES 2004 'Race, knowledge construction, and education in the USA: lessons from history', in Gloria Ladson-Billings and David Gillborn (eds), The RoutledgeFalmer Reader in Multicultural Education: Critical Perspectives on Race, Racism and Education, Abingdon: Routledge Falmer, pp. 16-34

BOLTANSKI, LUC 2007 l'amour et la justice comme compétances. Trois essais de sociologie de l'action, Paris: Gallimard

BORG, CARMEL and MAYO, PETER 2006 'Toward an Anti-Racist Agenda in Education: the case of Malta', in Donaldo Macedo and Panayota Gounari (eds), The Globalization of Racism, Boulder: Paradigm Publishers, pp. 148-64

BROWN, WENDY 2006 Regulating Aversion. Tolerance in the Age of Identity and Empire, Princeton, NJ: Princeton University Press

CARVALHO, MARIA MANUELA 1997 'Ensino da história e ideologia "imperial", História, Year XIX (New Series), 34, August/September, pp. 14-23

CASTELO, CLÁUDIA 1998 O modo português de estar no mundo': o luso-tropicalismo e a ideologia colonial portuguesa (1933-1961), Porto: Edições Afrontamento

COUNCIL OF EUROPE, 1995 Against Bias and Prejudice. The Council of Europe's Work on History Teaching and History Textbooks (Recommendations on History Teaching and History Textbooks Adopted at Council of Europe Conferences and Symposia 1953-1995), Strasbourg: Council for Cultural Co-operation 
COUNCIL OF EUROPE 1996 'Mutual understanding and the teaching of European history: challenges, problems and approaches', Symposium, Prague, Czech Republic, 24-28 October 1995. Report, Strasbourg: Council for Cultural Co-operation

COUNCIL OF EUROPE 2001 Recommendation Rec(2001)15 of the Committee of Ministers to Member States on History Teaching in Twenty-First-Century Europe. Available from: https://wcd.coe.int/wcd/ViewDoc.jsp?id =234237 [Accessed 25 July 2011]

CRUZ, BARBARA C. 2002 'Don Juan and rebels under palm trees: depictions of Latin Americans in US history textbooks', Critique of Anthropology, vol. 22, no. 3, pp. 323-42

FABIAN, JOHANNES 2002 Time and the Other. How Anthropology Makes its Object, New York: Columbia University Press

FOSTER, STUART 2006 'Whose history?', in Stuart Foster and Keith Crawford (eds), What Shall We Tell the Children?, Greenwich, CT: Information Age Publishing, pp. 131-44 FREDRICKSON, GEORGE M. 2002 Racism: A Short Story, Princeton, NJ: Princeton University Press

GILROY, PAUL 1992 'The end of anti-racism', in James Donald and Ali Rattansi (eds), 'Race', Culture, and Difference, London: Sage, pp. 49-61

GOLDBERG, DAVID T. 2002 'Modernity, race, and morality', in Philomena Essed and David Goldberg (eds), Race Critical Theories: Text and Context, Oxford: Blackwell, pp. 283306

GOLDBERG, DAVID THEO 2002 The Racial State, Oxford: Balckwell

GROSFOGUEL, RAMÓN 2009 'A decolonial approach to political-economy: transmodernity, border thinking and global coloniality', Kult 6 - Special Issue: Epistemologies of Transformation: The Latin American Decolonial Option and its Ramifications, Fall, pp. 1038. Available from: http://www.postkolonial.dk/artikler/grosfoguel.pdf [Accessed 25 July 2011]

HALL, STUART 1992 'The West and the rest: discourse and power', in Stuart Hall and Bram Gieben (eds), Formations of Modernity, Cambridge: Polity Pres, pp. 275-331

HANNAFORD, IVAN 2006 Race. The History of an Idea in the West, Washington, DC: The Woodrow Center Press

HESPANHA, ANTÓNIO 1999 Há 500 anos: balanço de três anos de comemorações dos descobrimentos portugueses 1996-1998, Lisboa: CNCDP

HESSE, BARNOR 2004 'Im/plausible deniability: racism's conceptual double Bind', Social Identities, vol. 10 , no. 1 , pp. $9-29$

JOHNSON, CAROL 2005 'Narratives of identity: denying empathy in conservative discourses on race, class, and sexuality', Theory and Society, vol. 34, no. 1, pp. 37-61

LENTIN, ALANA 2004 Racism and Anti-racism in Europe, London: Pluto Press 2008 Racism, Oxford: One World Publications

LESKO, NANCY and BLOOM, LESLIE 1998 'Close encounters: truth, experience and interpretation in multicultural teacher education', Journal of Curriculum Studies, vol. 30, no. 4, pp. $375-95$

MOSSE, GEORGE L. 1998 Toward the Final Solution: A History of European Racism, London: J.M. Dent

OLIVEIRA, ANA, CANTANHEDE, FRANCISCO, CATARINO, ISABEL and TORRÃO, PAULA 2008 Novo História 8. Scientific revision: João Alves Dias, Pedagogic revision: Marília Gago, Lisbon: Texto Editores - Year 8, vol. 1 [NH8-1]

PARASKEVA, JOÃO MENELAU 2006 'Portugal will always be an African nation: a Calibanian prospority or a prospering Caliban?', in Donaldo Macedo and Panayota Gounari (eds), The Globalization of Racism, London: Paradigm Publishers, pp. 241-68 PÉREZ-AGOTE, ALFONSO 1996 'La sociedad se difumina, el individuo se disgrega. Sobre la necesidad de historizar nuestras categorías', in Alfonso Pérez-Agote and Ignacio Sánchez de la Yncera (eds), Complejidad y Teoría Social, Madrid: CIS, pp. 11-32

PINGEL, FALK, et al. 2000 The European Home: Representations of 20th Century Europe in History Textbooks, Strasbourg: Council of Europe Publishing 
PROENÇA, MARIA CANDIDA 2001 'A república e a democratização do ensino' 2001 in Maria Cândida Proença (ed.) O sistema de ensino em Portugal (Séculos XIX-XX), Lisboa: Edições Colibri, pp. 47-70

QUIJANO, ANÍBAL 2000 'Coloniality of power, Eurocentrism and Latin America', Nepantla: Views from South, vol. 1, no. 3, pp. 533-80

SANTOS, MARIANA L. 2007 'A formação da mentalidade colonial: representações de portugal ultramarino em livros de leitura do Estado Novo', Revista de História das Ideias, vol. 28 , pp. 357-90

SCHAAP, ANDREW 2001 'Guilty subjects and political responsibility: Arendt, Jaspers and the Resonance of the "German Question" in politics of reconciliation', Political Studies, vol. 49 , no. 4 , pp. $749-66$

SOLOMOS, JOHN and BACK, LES 1996 Racism and Society, New York: Palgrave

SONTAG, SUSAN 2004 Regarding the Pain of Others, New York: Picador

SOYSAL, YASEMIN and SCHISSLER, HANNA 2005 'Introduction. Teaching beyond the national narrative', Yasemin Soysal and Hanna Schissler (eds), The Nation, Europe and the World. Textbooks in and Curricula in Transition, London: Berghan Books, pp. 1-9

SPIVAK, GAYARTI CHAKRAVORTY 2003 A Critique of the Postcolonial Reason. Toward a History of the Vanishing Present, Cambridge, MA: Harvard University Press

STRADLING, ROBERT 2001 Teaching 20th-Century European History, Strasbourg: Council of Europe

SWARTZ, ELLEN 1992 'Emancipatory narratives: rewriting the master script in the school curriculum', Journal of Negro Education, vol. 61, no. 3, pp. 341-55

SWEET, JAMES H. 2003 'Spanish and Portuguese influences on racial slavery in British North America, 1492-1619', V Annual Gilder Lehrman Center International Conference: Collective Degradation: Slavery and the Construction of Race, Yale University, 7-8 November TILLY, CHARLES 1992 Coercion, Capital and European States, AD 990-1992, Oxford: Blackwell

1994 'States and nationalism in Europe: 1492-1992', Theory and Society, vol. 23, no. 1, pp. $131-46$

VAKIL, ABDOOLKARIM 1996 'Nationalising cultural politics: representations of the Portuguese "Discoveries" and the rhetoric of identitarianism, 1880-1926', in Clare Mar-Molinero and Angel Smith (eds), Nationalism and the Nation in the Iberian Peninsula, Oxford: Berg, pp. 33-52

VAN DIJK, TEUN 1993 Elite Discourse and Racism, Newbury Park, CA: Sage

WALLERSTEIN, IMMANUEL 1997 'Eurocentrism and its avatars: the dilemmas of social science', New Left Review, I/226, November-December, pp. 93-107

WEST, CORNEL 1993 Prophetic Reflections: Notes on Race and Power in America, Monroe, ME: Common Courage Press

WOLF, ERIC R. 1997/1982 Europe and the People without History, Berkeley, CA: California University Press

\author{
MARTA ARAÚJO and SILVIA RODRÍGUEZ MAESO are both \\ researchers at the Centre for Social Studies, University of Coimbra \\ (Portugal). \\ ADDRESS: Centre for Social Studies, University of Coimbra, Colegio \\ de S. Jerónimo, Apartado 3087, 3001-401 Coimbra, Portugal. \\ Email:marta@ces.uc.pt and srodrig@ces.uc.pt
}




\section{Appendix: History textbooks cited}

BARREIRA, ANÍBAL and MOREIRA, MENDES 2008 Sinais $d a$ História 8. Scientific revision: Eugénio Francisco dos Santos, 2nd edn, Lisbon: Edições ASA [SH8]

DINIZ, MARIA EMíLIA, TAVARES, ADÉRITO and CALDEIRA, ARLINDO 2009 História SetelOito/Nove. Scientific revision: José Mattoso, Lisbon: Lisboa Editora

- Year 7 [LH7]

- Year 8, vol. 1 [LH8-1]

- Year 8, vol. 2 [LH8-2]

- Year 9, vol. 1 [LH9-1]

- Year 9, vol. 2 [LH9-2]

MAIA, CRISTINA, BRANDÃO, ISABEL P. and CARVALHO, MAKNUELA 2008 Viva a História! Scientific revision: Luís Miguel Duarte, Porto: Porto Editora

- Year 7, vol. 1 [VH7-1]

- Year 7, vol. 2 [VH7-2]

OLIVEIRA, ANA, CANTANHEDE, FRANCISCO, CATARINO, ISABEL and TORRÃO, PAULA 2008 História 8. Scientific revision: João Alves Dias, Pedagogic revision: Marília Gago, Lisbon: Texto Editores

- Year 8, vol. 1 [H8]

OLIVEIRA, ANA, CANTANHEDE, FRANCISCO, CATARINO, ISABEL and TORRÃO, PAULA 2008 Novo História 9. Scientific revision: João Alves Dias, Pedagogic revision: Marília Gago, Lisbon: Texto Editores

- Year 9 [NH9] 